\title{
New heterogeneous catalyst for the esterification of fatty acid produced by surface aromatization/sulfonation of oilseed cake
}

\author{
Eleonice Moreira Santos ${ }^{\mathrm{a}, *}$, Ana Paula de Carvalho Teixeira ${ }^{a}$, Flávia Gontijo da Silva ${ }^{a}$, \\ Thérèse Ebambi Cibaka ${ }^{a}$, Maria Helena Araújo ${ }^{a}$, Willian Xerxes Coelho Oliveira ${ }^{a}$, Felipe Medeiros ${ }^{a}$, \\ Alex Nogueira Brasil ${ }^{\mathrm{b}}$, Leandro Soares de Oliveira ${ }^{\mathrm{a}}$, Rochel Montero Lago ${ }^{\mathrm{a}, *}$ \\ ${ }^{a}$ Departamento de Química, Instituto de Ciências Exatas, Universidade Federal de Minas Gerais, Belo Horizonte-MG 31270-901, Brazil \\ ${ }^{\mathrm{b}}$ Biominas Engineering Industry, Itaúna, MG, Brazil
}

\section{H I G H L I G H T S}

- Simple sulfonation of biodiesel waste cake in mild conditions produces a new and active heterogeneous acid catalyst.

- The catalytic activity is comparable to $\mathrm{H}_{2} \mathrm{SO}_{4}$ and the catalyst can be reused several times.

- The catalyst combines a carbon-sulfonic acid surface with a very hydrophilic cellulose surface responsible for water removal.

\section{A R T I C L E I N F O}

\section{Article history:}

Received 30 September 2014

Received in revised form 6 February 2015

Accepted 8 February 2015

Available online 16 February 2015

\section{Keywords:}

Acid catalyst

Oleic acid

Esterification

Biodiesel cake

Aromatization

Sulfonation

\begin{abstract}
A B S T R A C T
In this work, an efficient heterogeneous acid catalyst for the esterification of oleic acid was prepared directly from oilseed cake by a simple sulfonation with concentrated $\mathrm{H}_{2} \mathrm{SO}_{4}$. Characterization by SEM/EDS, IR, Raman, TG, TG/MS, potentiometric titration showed that treatment with $\mathrm{H}_{2} \mathrm{SO}_{4}$ for 1,2 and $4 \mathrm{~h}$ at $120^{\circ} \mathrm{C}$ partially dehydrates the cake to form a carbon/cellulose composite which is sulfonated to produce strong $-\mathrm{SO}_{3} \mathrm{H}$ acidic sites. These surface sites were active for the esterification of oleic acid with yields ca. $84 \%, 88 \%$ and $94 \%$ in the presence of 5,10 and 20 wt\% catalyst, respectively. These results are comparable to $98 \%$ yield obtained with $1 \mathrm{wt} \% \mathrm{H} 2 \mathrm{SO} 4$ and higher than $75 \%$ observed for a high surface area $\left(880 \mathrm{~m}^{2} \mathrm{~g}^{-1}\right)$ sulfonated activated carbon with similar number of $-\mathrm{SO} 3 \mathrm{H}$ active groups. These results are discussed in terms of two effects: (i) the number of sulfonic surface acidic groups and (ii) the presence of a hydrophilic cellulosic fraction in the catalyst that adsorbs/traps water formed in the reaction shifting the esterification equilibrium and improving the yield.
\end{abstract}

(C) 2015 Elsevier Ltd. All rights reserved.

\section{Introduction}

The transesterification reaction to produce biodiesel in the presence of basic homogeneous catalysts, e.g. $\mathrm{KOH}, \mathrm{NaOH}$ or methoxides, has been extensively investigated in the last decade [1-4]. It is well established that this alkaline catalyzed transesterification is strongly affected by the presence of free fatty acids [4,5]. The presence of these acids in concentrations higher than ca. $2 \%$ can hinder the reaction and form surface active molecules with significant complications in the purification step due to the formation of stable emulsions [6].

\footnotetext{
* Corresponding authors at: Departamento de Química, Universidade Federal de Minas Gerais - UFMG, Av. Antônio Carlos, 6627, Pampulha, Belo Horizonte-MG 31270-901, Brazil. Tel.: +55 3134095719.

E-mail address: rochel@ufmg.br (R.M. Lago).
}

An alternative route to deal with acidic oils is typically a previous esterification in the presence of $\mathrm{H}_{2} \mathrm{SO}_{4}$ as catalyst [7]. However, sulfuric acid is corrosive and cannot be recovered [8,9]. In this respect, the development of an active acid heterogeneous catalyst to produce biodiesel using acidic oils is of considerable interest. Heterogeneous catalysts can be easily removed and reused avoiding the washing step which simplifies the process [10-13].

Different types of acidic materials, such as zeolites [14-16]; mesoporous silica [17-19], resins [20,21], oxides, e.g. zinc, titanium, strontium oxides [22-24], zirconia [25-28], supported carbon nanotubes [29] and minerals such as a mordenite, kaolins, halloysite [30-32] have been investigated as catalyst for the esterification reaction. Also promising carbon based acid catalysts have been prepared by pyrolysis followed by sulfonation with sulfuric acid, using different precursors such as carbohydrates, lignin [33,34], sugar cane bagasse [35], fibers [36], biochar [37], resin 


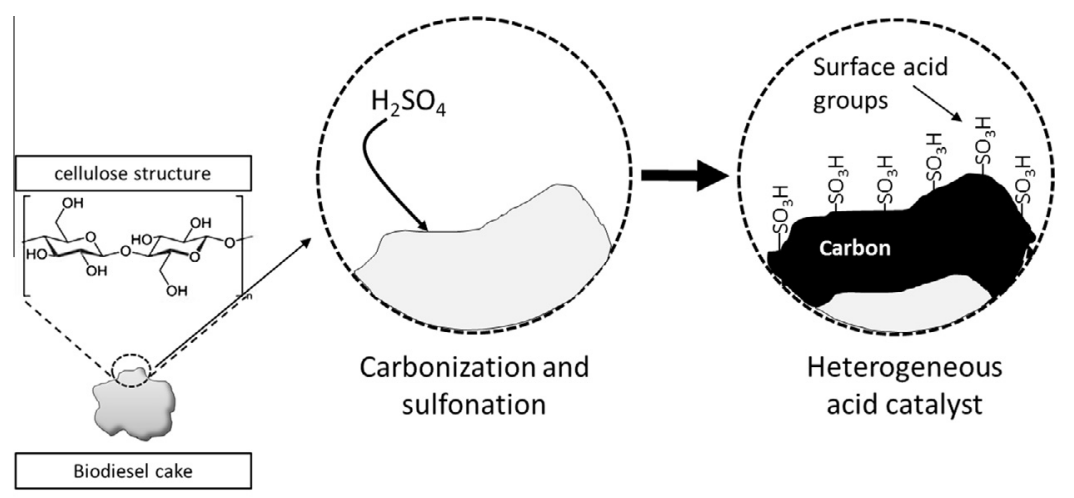

Fig. 1. Representation of the partial aromatization/sulfonation reaction of the biodiesel cake to produce the composite acid catalyst.

[38], bean vermicelli [39], de-oiled canola [40], polymers [41], D-glucose and sulfonated ordered mesoporous carbons [42-46]. These catalysts have shown great potential to replace the traditional homogeneous $\mathrm{H}_{2} \mathrm{SO}_{4}$ catalysis.

In this work, we present a new and simple reaction procedure to prepare an active heterogeneous catalyst from oilseed cake, a biodiesel byproduct. Biodiesel cakes are solid materials obtained after oil extraction by mechanical pressing, consisting mainly of lignocellulosic fibers. The high concentrations of lignocellulosic material, deficiency of proteins and the presence of some toxic compounds strongly limit the use of some biodiesel cakes in feed blends for ruminant animals $[47,48]$. The active acid catalyst can be produced by the direct reaction of the cake with sulfuric acid according to the simplified scheme shown in Fig. 1.

The reaction with concentrated sulfuric acid with the lignocellulosic waste seems to promote surface reactions likely based on dehydration with aromatization followed by sulfonation producing the acid catalytic sites. The synthesis, characterization and use of this heterogeneous acid catalyst for the esterification of oleic acid in bench and pilot/ultrasound scale are described below.

\section{Material and methods}

Different biodiesel cakes obtained after extraction of sunflower, castor, jatropha, curcas and macaw palm oil can be used as solid lignocellulosic precursor. In a typical procedure the biodiesel cake ( $1 \mathrm{~g}$, ground to particles smaller than $2 \mathrm{~mm}$ and dried overnight at $80{ }^{\circ} \mathrm{C}$ ) was mixed with concentrated $\mathrm{H}_{2} \mathrm{SO}_{4}$ (min $98 \%, 8 \mathrm{~mL}$, Synth $^{\circledR}$ ), under stirring, at room temperature for $1 \mathrm{~h}$ (sample CK1rt) and at $120 \pm 5^{\circ} \mathrm{C}$ for 1,2 and $4 \mathrm{~h}$ (samples CK1, CK2 and CK4, respectively). Due to the exothermicity of the reaction, the process should be well controlled in order to avoid overheating and dissipate possible hot spots generated on the precursor surface. Caution should be taken to control after the reaction the black solid was extensively washed with water (until reaching $\mathrm{pH} \sim 7$ ) and dried at $80^{\circ} \mathrm{C}$ for $12 \mathrm{~h}$. Raman spectroscopy measurements were made using a Senterra Raman spectrometer from Bruker using a CCD detector, equipped with an optical microscope (OLYMPUS BX51) and a laser at $633 \mathrm{~nm}$. Thermal analyses (TG/DTG) were performed in a Shimadzu $60 \mathrm{H}$ under nitrogen flow $\left(100 \mathrm{~mL} \mathrm{~min}^{-1}\right)$ and heating rate of $10^{\circ} \mathrm{C} \mathrm{min-1}$ up to $900{ }^{\circ} \mathrm{C}$. Scanning Electron Microscopy (SEM/EDS) results were obtained in a Quanta 200 - FEG - FEI 2006. FTIR spectra were obtained with $\mathrm{KBr}$ pellets in a Perkin Elmer FTIR GX instrument. Potentiometric titration was carried out in an automatic titrator Metrhomn 670 with a mixture of $25 \mathrm{mg}$ of the sample dispersed in $0.01 \mathrm{~mol} / \mathrm{L}$ of $\mathrm{HCl}$ and $0.1 \mathrm{~mol} / \mathrm{L}$ of $\mathrm{NaCl}$ and titrated with $0.010 \mathrm{~mol} / \mathrm{L}$ of $\mathrm{NaOH}$ solution. The thermogravimetric-mass spectrometry (TG-MS) analysis were performed in a NETZSCH TGA model STA 449 F3, coupled to a mass spectrometer
NETZSCH Aëolos model QMS 403C. About $20 \mathrm{mg}$ of the sample was used an argon flow in the purge and protective lines, both at $20 \mathrm{~mL} / \mathrm{min}$, and with heating rate of $10^{\circ} \mathrm{C} \mathrm{min}^{-1}$ up to $900{ }^{\circ} \mathrm{C}$. Gaseous species released from the sample during the heating were drawn into an alumina tube fixed inside the furnace of the thermobalance close to the sample, connected to a capillary silica column heated at $300^{\circ} \mathrm{C}$. The gases were then directly sucked into the ionization chamber of the mass spectrometer.

The catalytic activity of the materials was tested in the esterification of pure oleic acid in a round bottom flask fitted with a reflux condenser at $60^{\circ} \mathrm{C}$ for $2 \mathrm{~h}$, with a ratio of $12: 1$ methyl alcohol:oleic acid and different catalyst concentrations $(5,10$ or $20 \mathrm{wt} \%$, with respect of oleic acid concentration). After the reaction the catalyst (ca. $1 \mathrm{~g}$ ) was washed with ethanol ( $30 \mathrm{~mL}$ at room temperature) and dried at $80^{\circ} \mathrm{C}$ for $4 \mathrm{~h}$ and tested in the reuse experiments. The conversion of methyl esters was analyzed by the Ca 5a-40/ AOCS method and confirmed by $1 \mathrm{H}$ NMR. (RMN Bruker Advance DPX 200). The signals used as references were of the methoxy groups in the methyl ester ( $3.7 \mathrm{ppm}$ ) and of the $\alpha$-carbonyl methylene groups present in the oil and biodiesel (2.1 ppm) [49]. A calibration curve from the $1 \mathrm{H}$ NMR spectra of oil/biodiesel mixtures using the $3.7 \mathrm{ppm}$ and $2.3 \mathrm{ppm}$ area ratio was obtained.

The catalytic activity of the materials was also investigated at a pilot plant scale using an ultrasound promoted reactor (see Supplementary Material - Fig. 1S) [50].

Commercially available activated carbon (from coconut shell, $880 \mathrm{~m}^{2} \mathrm{~g}^{-1}$, Sulfal) was used as a catalyst in a control reaction study. The activated carbon was sulfonated using the same conditions used for preparation of CK2 (sulfonation with concentrated $\mathrm{H}_{2} \mathrm{SO}_{4}$ for $2 \mathrm{~h}$ at $120^{\circ} \mathrm{C}$ under stirring and washed with water $(\mathrm{pH} \sim 7)$ and dried at $80^{\circ} \mathrm{C}$ for $12 \mathrm{~h}$ ). The water absorption capacity of the CK2 material was determined by the "tea bag" method by weighing the water retained by the material [51].

\section{Results and discussion}

Biodiesel cakes from different sources, e.g. sunflower, castor, jatropha curcas and macaw palm are composed mainly of lignocellulosic fibers. In contact with sulfuric acid the lignocellulosic material becomes completely black suggesting a strong dehydration process to form polyaromatic/carbon on the surface. The reaction with $\mathrm{H}_{2} \mathrm{SO}_{4}$ was carried out at room temperature for $1 \mathrm{~h}$ (sample CK1rt) and at $120^{\circ} \mathrm{C}$ for 1,2 and $4 \mathrm{~h}$ (samples CK1, CK2 and CK4 respectively).

Raman analyses (Fig.2) for all the obtained solids after reaction with sulfuric acid at $120^{\circ} \mathrm{C}$, showed two typical bands for carbonaceous materials: the $D$ and the $G$ band. The $G$ band (at $1590 \mathrm{~cm}^{-1}$ ) is typical for well-formed and organized graphitic structures whereas the $\mathrm{D}$ band (near $1350 \mathrm{~cm}^{-1}$ ) indicates the presence of 


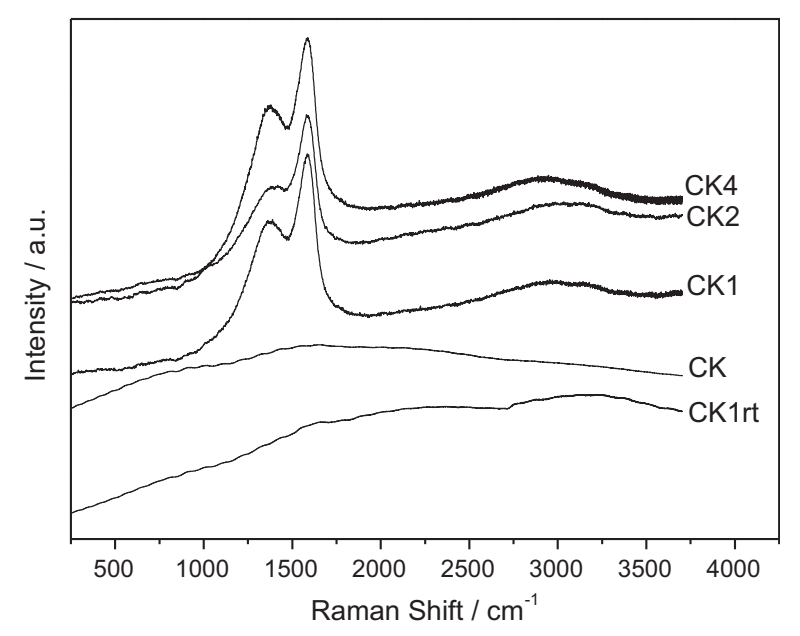

Fig. 2. Raman spectra of $\mathrm{CK}$ samples after reaction with concentrated $\mathrm{H}_{2} \mathrm{SO}_{4}$.

defects or amorphous carbon [52] confirming the carbonization process of the cake material. These bands are not observed in the material obtained at room temperature, $\mathrm{CK} 1 \mathrm{rt}$, indicating no significant reaction with $\mathrm{H}_{2} \mathrm{SO}_{4}$. Moreover, due to exothermicity of the reaction at $120^{\circ} \mathrm{C}$ local temperatures might significantly raise to generate hot spots which can contribute to the pyrolysis process.

TG and DTG analyses (in $\mathrm{N}_{2}$ ) of the dry cake before reaction (Fig. 3) showed a weight loss between 200 and $500{ }^{\circ} \mathrm{C}$ of $\mathrm{ca} .80 \%$ associated to the decomposition of lignocellulose to produce mainly $\mathrm{CO}_{2}, \mathrm{H}_{2} \mathrm{O}$ and other small volatile molecules [53]. Similar TG profile was obtained for the sample $\mathrm{CK} 1 \mathrm{rt}$. On the other hand, the materials after reaction at $120^{\circ} \mathrm{C}$ showed weight losses of only ca. $35-50 \%$. These smaller weight losses are likely related to the decomposition of the remaining lignocellulose present in the materials.

FTIR spectra (Fig. 4) of the cake showed typical absorptions observed in lignocellulosic materials. The intense band at $3340 \mathrm{~cm}^{-1}$ is assigned to the $\mathrm{O}-\mathrm{H}$ stretching vibration, bands at 2893 and $1431 \mathrm{~cm}^{-1}$ characteristic of $\mathrm{C}-\mathrm{H}$ stretching and bands at 1190 and $1000 \mathrm{~cm}^{-1}$ are related to the saccharide structure [54]. After acid dehydration a significant change in the IR spectrum was observed with strong changes in the absorptions at 1190 and $1000 \mathrm{~cm}^{-1}$ and a narrowing of the band at $3340 \mathrm{~cm}^{-1}$. On the other hand, new bands appeared, i.e. 1029 and $1160 \mathrm{~cm}^{-1}$, related to the

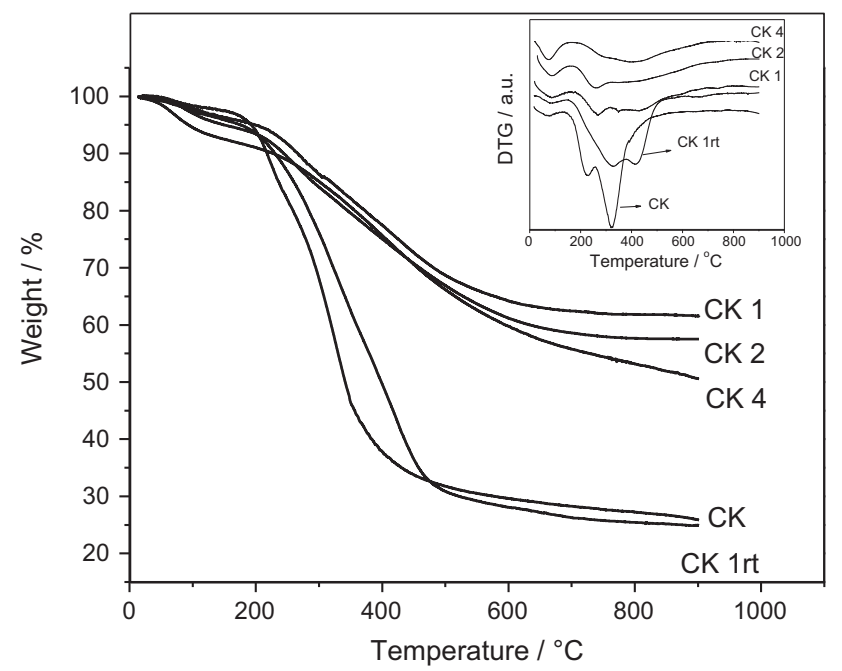

Fig. 3. TG and DTG analyses of the materials CK, CK1rt, CK1, CK2, CK4, under nitrogen atmosphere.

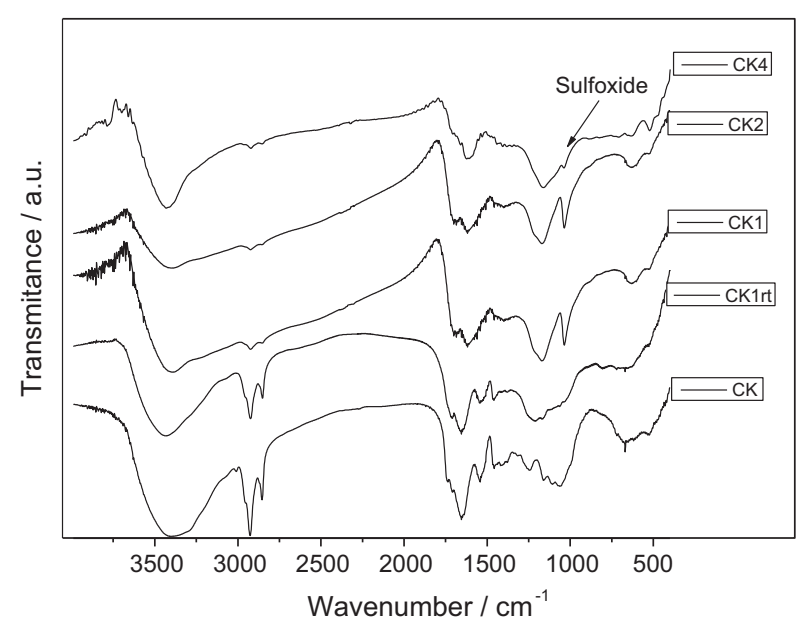

Fig. 4. FTIR spectra of the materials CK, CK1rt, CK1, CK2, CK4.

symmetric stretching vibrations of $\mathrm{O}=\mathrm{S}=\mathrm{O}$ in $-\mathrm{SO}_{3} \mathrm{H}$ groups [38,55-57] and another at $620 \mathrm{~cm}^{-1}$ related to the bending vibration of $-\mathrm{OH}$ groups hydrogen bonded to $-\mathrm{SO}_{3} \mathrm{H}$ [57], mainly in $\mathrm{CK} 1$ and CK2 samples. In addition, intense absorptions are observed between 1500 and $1800 \mathrm{~cm}^{-1}$ likely related to aromatic $\mathrm{C}=\mathrm{C}$ $\left(\sim 1600 \mathrm{~cm}^{-1}\right)$ and $\mathrm{C}=\mathrm{O}$ from various functional groups as carboxyl $\left(1729 \mathrm{~cm}^{-1}\right)$ and quinone $\left(1550-1680 \mathrm{~cm}^{-1}\right)$ [58].

Fig. 5 shows the potentiometric titration curves of the CK catalysts with $\mathrm{NaOH}$. The number of acidic sites and $\mathrm{pKa}$ obtained are displayed in Table 1.

It can be observed that the CK and CK1rt showed total groups concentration of $1.2-1.7 \mathrm{mmol} \mathrm{g}^{-1}$, mainly as weak acidic groups. As the cake was treated with $\mathrm{H}_{2} \mathrm{SO}_{4}$, more acidic groups were formed, $3.0-3.3 \mathrm{mmol} \mathrm{g}^{-1}$. It can be observed that very acidic groups are formed with pKa lower than 2 . These groups are likely related to $-\mathrm{SO}_{3} \mathrm{H}$.

It is interesting to observe that longer reaction times, i.e. $4 \mathrm{~h}$, led to a decrease of the number of acidic groups. This is probably related to the hydrolysis/decomposition of the surface groups [51].

SEM analyses (Fig. 6) suggests that the surface texture of the cake does not change significantly after $\mathrm{H}_{2} \mathrm{SO}_{4}$ reaction. In fact, the BET surface area (ca. $0 \mathrm{~m}^{2} \mathrm{~g}^{-1}$ ) and porosity of the precursor $\mathrm{CK}$ also did not change after $\mathrm{H}_{2} \mathrm{SO}_{4}$ treatment. EDS data clearly showed the presence of sulfur after reactions with $\mathrm{H}_{2} \mathrm{SO}_{4}$ due to the sulfonation reaction.

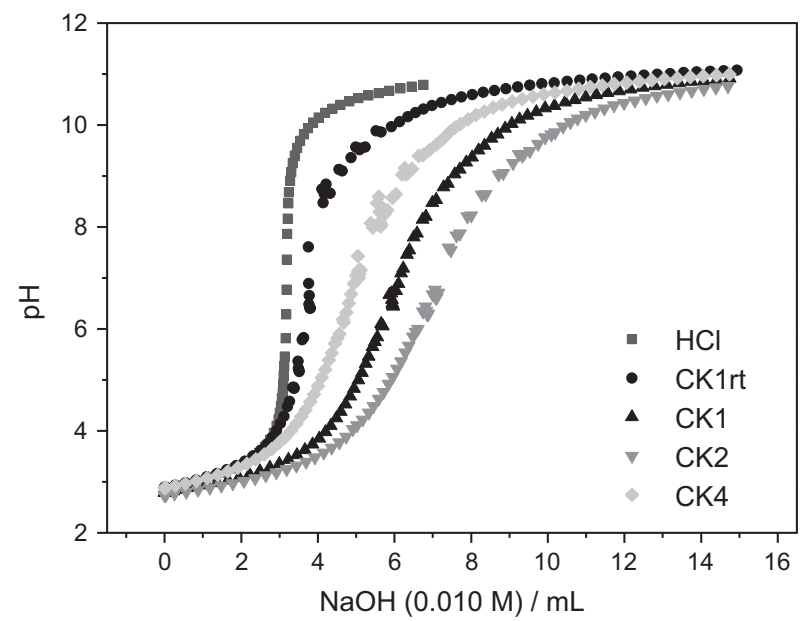

Fig. 5. Potentiometric titration of the materials $\mathrm{CK}, \mathrm{CK} 1 \mathrm{rt}, \mathrm{CK} 1, \mathrm{CK} 2, \mathrm{CK} 4$. 
Table 1

Results of potentiometric titrations for biodiesel cake, before and after reaction with $\mathrm{H}_{2} \mathrm{SO}_{4}$.

\begin{tabular}{|c|c|c|c|c|c|}
\hline \multirow[t]{2}{*}{ Sample } & \multicolumn{4}{|c|}{ Acidic functional groups $\left(\mathrm{mmol} \mathrm{g}^{-1}\right)$} & \multirow[t]{2}{*}{ Total of acids $\left(\mathrm{mmol} \mathrm{g}^{-1}\right)$} \\
\hline & $(\mathrm{p} K \mathrm{a}<2.5)$ & $4<\mathrm{pKa}<6$ & $6<\mathrm{pKa}<8$ & $8<\mathrm{pKa}<10$ & \\
\hline CK & - & 0.45 & 0.53 & 0.22 & 1.2 \\
\hline CK1rt & - & 0.47 & 0.04 & 1.20 & 1.7 \\
\hline CK1 & 0.43 & 0.83 & 0.34 & 1.36 & 3.0 \\
\hline CK2 & 0.68 & 0.91 & 0.74 & 0.93 & 3.3 \\
\hline CK4 & - & 1.00 & 0.51 & 1.10 & 2.6 \\
\hline
\end{tabular}
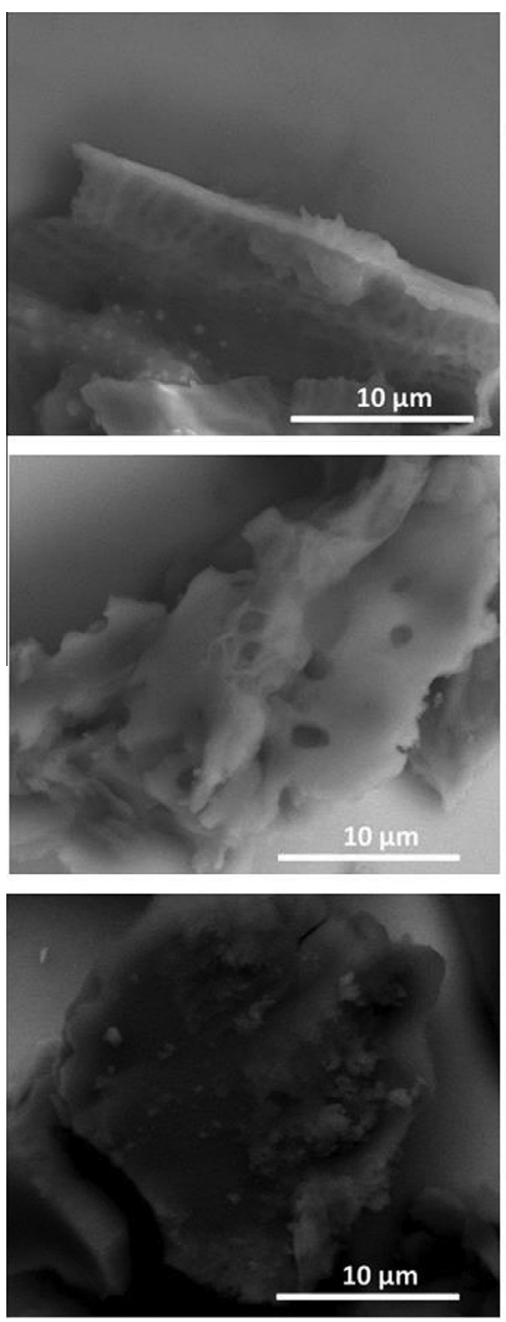
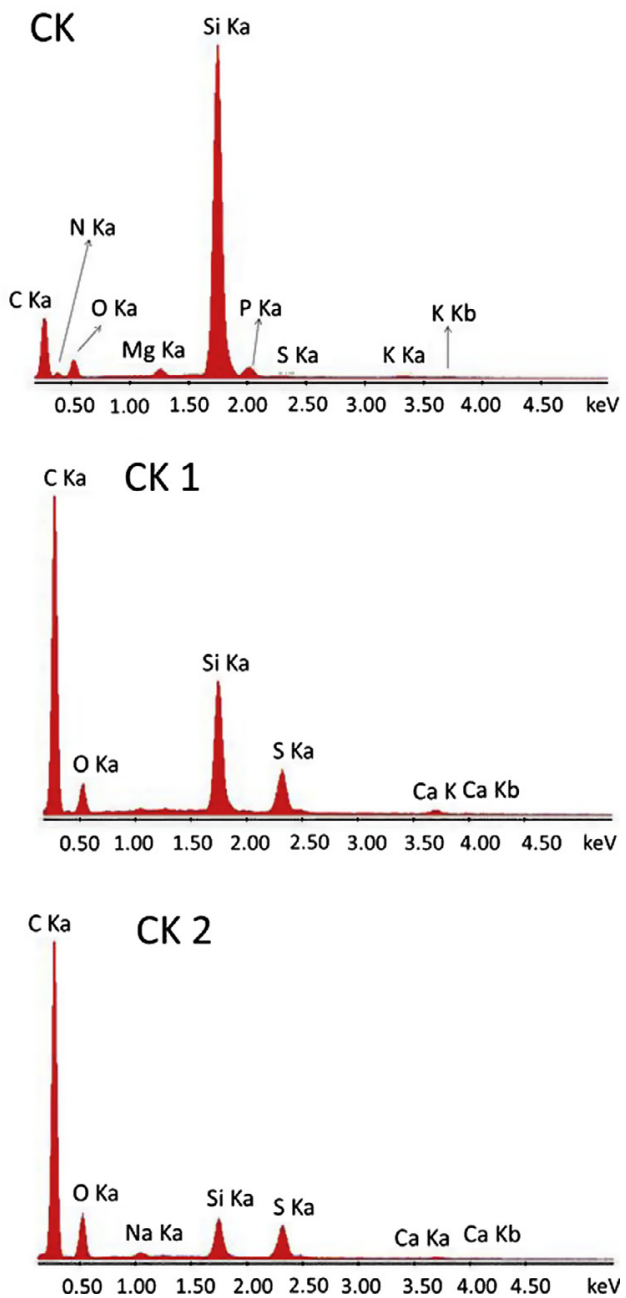

Fig. 6. SEM/EDS images of the materials CK, CK1 and CK2.

The CK and CK2 samples were also characterized by TG/MS. Fig. 7 shows the TG/MS profiles for some specific molecules. It is possible to observe that the $\mathrm{CK}$ sample loses $\mathrm{m} / \mathrm{z} 18$ near $100{ }^{\circ} \mathrm{C}$ related to adsorbed water. It can also be observed a water loss $150-350{ }^{\circ} \mathrm{C}$ related to cellulose decomposition. After sulfonation for $2 \mathrm{~h}$ (CK2) the TG/MS profiles suggests the presence of some adsorbed water but the cellulose decomposition signal is much less intense, suggesting that $\mathrm{H}_{2} \mathrm{SO}_{4}$ has previously dehydrated the cake. The profile for $\mathrm{m} / \mathrm{z} 44$ signal also decreases in intensity after sulfonation which is also likely due to deoxygenation reactions caused by sulfuric acid. It is interesting to observe an intense $\mathrm{m} / \mathrm{z}$ signal 64 related to $\mathrm{SO}_{2}$ produced in the sulfonated CK2 material which suggests the presence of $-\mathrm{SO}_{3} \mathrm{H}$ groups.

The esterification of oleic acid was investigated using the sample CK2 since it showed the highest concentration of surface acid sites. Different catalyst concentrations were used, i.e. 5, 10 and $20 \mathrm{wt} \%$ relative to oleic acid. The esterification yields after $2 \mathrm{~h}$ reaction are shown in Fig. 8 (see SM Fig. S3 results for ester yields vs reaction time).

It can be observed yields near 84,88 and $94 \%$ in the presence of 5,10 and $20 \mathrm{wt} \%$ of catalyst, respectively. It is interesting to observe that the use of the classical homogeneous reaction with $1 \mathrm{wt} \% \mathrm{H}_{2} \mathrm{SO}_{4}$ showed yield near $98 \%$. Sulfuric acid $\left(\mathrm{H}_{2} \mathrm{SO}_{4}\right)$ is very acidic with pKa of -3 (first ionization) and 2 (second ionization) [59] and potentially affords $2 \mathrm{H}^{+}$for the reaction. Catalyst concentration of $1 \mathrm{wt} \% \mathrm{H}_{2} \mathrm{SO}_{4}$ corresponds to $20 \mathrm{mmol} \mathrm{H}^{+} / 100 \mathrm{~g}$ of oleic acid. For the CK2 heterogeneous catalyst it can be considered as catalytically active sites sulfonic acid surface groups which should have $\mathrm{pKa}$ near between -2 and -3 (see for example benzene sulfonic acid with $\mathrm{pKa}$ of -2.8 ) [59]. According to titration results 


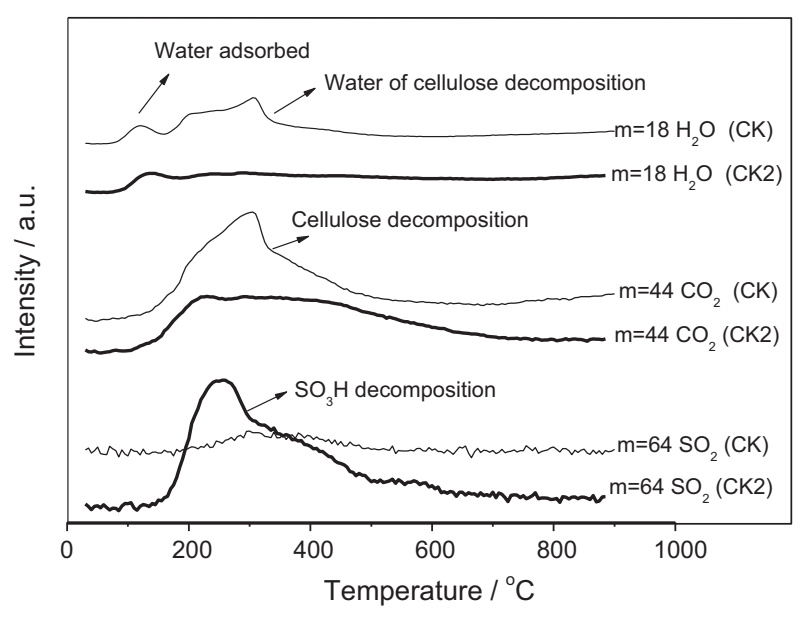

Fig. 7. TG/MS profiles of the samples CK and CK2.

the surface groups with $\mathrm{pKa}<2.5$ corresponds to ca. $0.68 \mathrm{mmol} \mathrm{g}^{-1}$ for the catalyst CK2 (see Table 1). Therefore, 5, 10 and $20 \mathrm{wt} \%$ of catalyst in the reaction corresponds to $3.4,6.8$ and $13.6 \mathrm{mmol}$ $\mathrm{H}^{+} / 100$ g oleic acid. It is interesting to observe that the CK2 shows similar catalytic activity with even lower concentration of catalytic species. It is also interesting to compare the CK2 catalyst (near no surface area ca. $0 \mathrm{~m}^{2} \mathrm{~g}^{-1}$ ) with a high surface area activated carbon $\left(890 \mathrm{~m}^{2} \mathrm{~g}^{-1}\right)$ sulfonated under the same conditions $\left(2 \mathrm{~h}\right.$ at $120^{\circ} \mathrm{C}$ with $\mathrm{H}_{2} \mathrm{SO}_{4}$ concentrated). This catalyst showed total acid concentration of $3.15 \mathrm{mmol} \mathrm{g}^{-1}$ however with lower esterification yield, $75 \%$, compared with the CK2. Turnover number calculation after $2 \mathrm{~h}$ reaction showed for the catalyst CK2 (20\%) $4.6 \mathrm{~mol}_{\text {ester }} \mathrm{mol}_{\text {site }}$ whereas the activated carbon $\mathrm{AC}-\mathrm{SO}_{3}$ showed TON of $3.9 \mathrm{~mol}_{\text {ester }}$

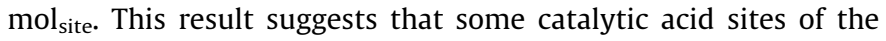
activated carbon are not active for the reaction likely due to the location inside the not accessible small micro pores.

Catalyst reuse was carried out with the sample CK2 at $10 \mathrm{wt} \%$ under mechanical stirring without any treatment between the reactions (Fig. 9).

After the first use the yield decrease from $88 \%$ to $\mathrm{ca}$. $66 \%$. In the subsequent cycles there was a decrease of the $10 \%$ in ester yield every cycle. The catalyst used in the 4 th reaction was regenerated by ethanol washing characterized by thermal analysis in nitrogen atmosphere (see SM Fig. S4). It is possible to observe a weight loss of $4 \%$ at temperatures below $150{ }^{\circ} \mathrm{C}$, relating to the loss of water/alcohol adsorbed. In addition, the material still lost 35\% weight at temperatures between 150 and $300{ }^{\circ} \mathrm{C}$. This loss can be attributed to the contamination of the catalyst by oleic acid or biodiesel.

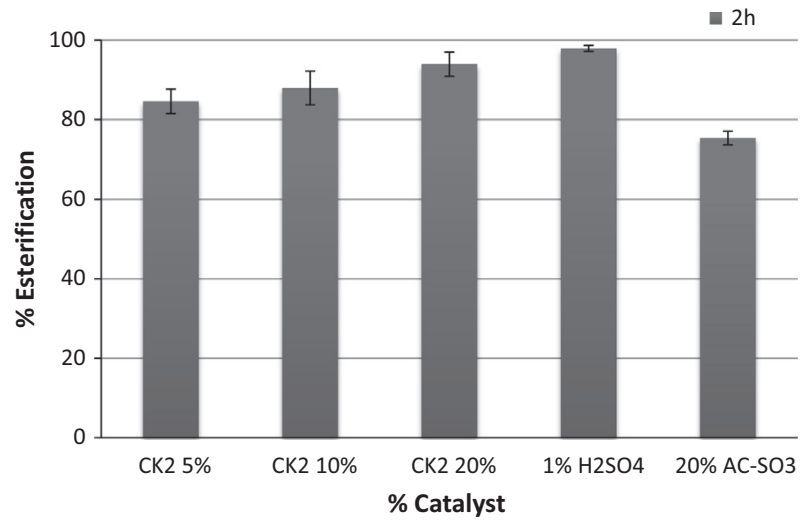

Fig. 8. Esterification yield of oleic acid using the catalyst $\mathrm{CK} 2, \mathrm{H}_{2} \mathrm{SO}_{4}$, and sulfonated commercial activated carbon (AC-SO3) by mechanical stirring after 2 h reaction.

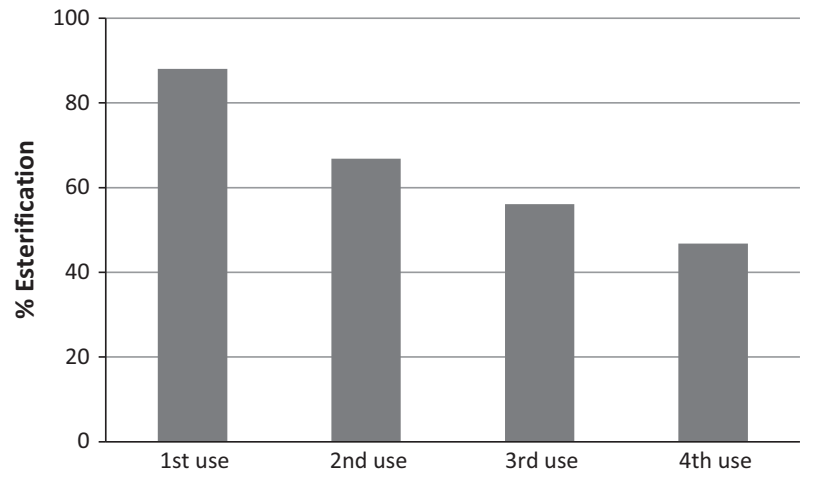

Fig. 9. Esterification yields for different reuses with $10 \mathrm{wt} \%$ of CK2 after $2 \mathrm{~h}$ reaction with mechanical stirring.

Preliminary scale up experiments in ultrasonic reactor produced by the company Biominas (see reactor in SM, Fig. S1) were carried out for the esterification of oleic acid (Fig. 10).

It can be observed for pilot scale ultrasound stirring similar ester yields obtained by mechanical stirring bench experiments. Reactions in the presence of 5, 10 and 20\% showed similar behavior as in mechanical stirring bench experiments (see SM - Fig. S5). The $20 \%$ CK2 heterogeneous catalyst showed esterification yield higher than $90 \%$ which was comparable to $1 \% \mathrm{H}_{2} \mathrm{SO}_{4}$ used as control.

The reuse of the catalyst CK2 (10\%) under ultrasound stirring showed a decrease from $86 \%$ to $81 \%, 56 \%$ and $48 \%$ for the $1 \mathrm{st}$, 2nd, 3rd and 4th reuse.

Previous works used sulfonated carbons as heterogeneous catalysts for the esterification of fatty acids. The carbons used were produced by pyrolysis of different vegetable precursors such as lignin [33], cane bagasse [35], mung bean [39], canola [40] and sugars [60]. In all these studies, the precursors had to be previously carbonized at high temperature $\left(400-800^{\circ} \mathrm{C}\right)$ under controlled atmosphere and only after pyrolysis underwent sulfonation. The obtained results showed only moderate yields of ca. $80 \%$ which could be increased to higher than $90 \%$ at high temperatures and prolonged reactions (5-24 h).

The catalysts prepared in this work did not need a preliminary carbonization step and the sulfonation was carried out directly on the lignocellulosic precursor waste under mild reaction conditions. Another feature of the CK catalysts is that the carbonization and sulfonation is only partial and part of the lignocellulosic structure remains in the material as suggested by IR and TG analyses. This lignocellulosic structure has a high concentration of surface $\mathrm{OH}$ groups and shows a strong hydrophilic character. This hydrophilic surface can have the effect of water adsorption which can be

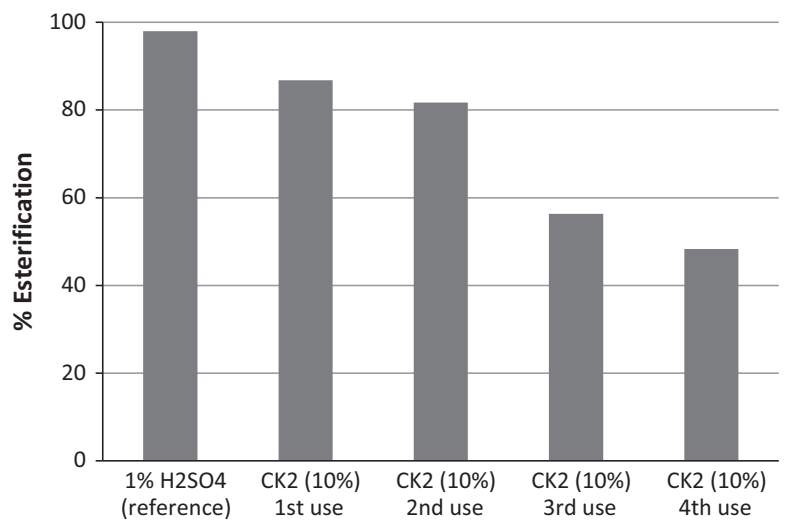

Fig. 10. Esterification yield of oleic acid using the catalyst $\mathrm{H}_{2} \mathrm{SO}_{4}(1 \%)$ and $\mathrm{CK} 2(10 \%$, $2 \mathrm{~h}$, methanol/oleic acid 12:1) in ultrasonic reactor and reuse experiments. 


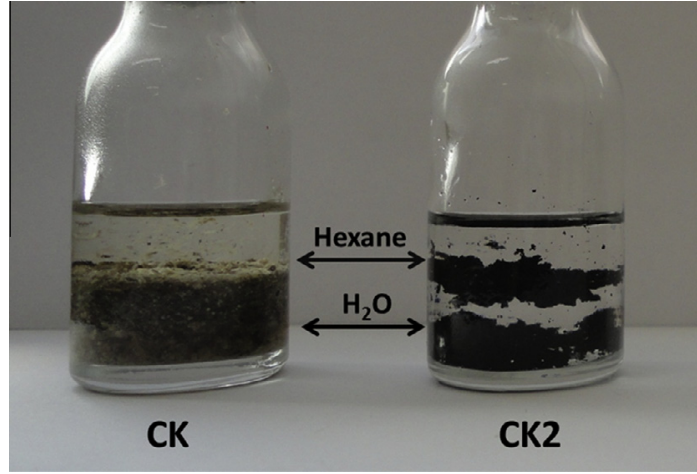

Fig. 11. Behavior of materials $C K$ and $C K 2$ in contact with a biphasic mixture of water and hexane.

beneficial for the esterification reaction since the water molecules are directly involved in the reaction equilibrium.

In fact, water absorption experiments showed that the CK2 material can absorb a high amount of water, i.e. $30 \mathrm{~g}_{\mathrm{H} 2 \mathrm{O}} / \mathrm{g}_{\text {catalyst }}$ ( $($ see $\mathrm{SM}$ Fig. S6). This water absorption can be a potential advantage over the homogeneous $\mathrm{H}_{2} \mathrm{SO}_{4}$ catalyst that does not have any effect on the $\mathrm{H}_{2} \mathrm{O}$ formed in the reaction. On the other hand, the carbonized surface has a more hydrophobic character which is important for the interaction/interface with the oil or oleic acid. Fig. 11 shows the behavior of materials CK (cake without sulfonation) and CK2 in the presence of water/hexane two phases mixture. It is possible to observe that the cake $\mathrm{CK}$, before sulfonation, presents a hydrophilic character and immediately goes to the aqueous phase. For the CK2 (after the sulfonation) the material initially stays at the interface water/hexane suggesting an amphiphilic character due to the combination of hydrophilic cellulose fraction with the carbonized surface. However, after few minutes the black solid migrates to the aqueous phase due to the wetting of the hydrophilic surface. The reaction medium is an emulsion of the hydrophobic oleic acid and the hydrophilic methanol. An amphiphilic catalyst is very important to contact these reactants and promote the reaction. The hydrophilic surface is important to interact with the polar methanol.

\section{Conclusion}

Cakes obtained after oil extraction can be converted by a simple process of aromatization/sulfonation with $\mathrm{H}_{2} \mathrm{SO}_{4}$ into a new type of heterogeneous catalyst for the esterification of free fatty acids. The produced catalyst showed activities comparable to the homogeneous $\mathrm{H}_{2} \mathrm{SO}_{4}$ catalyst and could be recovered and reused several times. The catalytic activity is discussed in terms of sulfonic groups $\left(-\mathrm{SO}_{3} \mathrm{H}\right)$ combined with an amphiphilic surface composed of carbon (more hydrophobic) which interacts well with the fatty acid and non-decomposed cellulose (more hydrophilic) which is responsible for water adsorption during the esterification reaction. Preliminary tests, showed that this heterogeneous catalyst can also be used in the production of biodiesel from low quality/high free acidity oils with the important advantage of eliminating the washing step.

\section{Acknowledgements}

The authors acknowledge financial support from CNPq, CAPES, FAPEMIG and Petrobras.

\section{Appendix A. Supplementary material}

Supplementary data associated with this article can be found, in the online version, at http://dx.doi.org/10.1016/j.fuel.2015.02.027.

\section{References}

[1] Maddikeri GL, Pandit AB, Gogate PR. Intensification approaches for biodiesel synthesis from waste cooking oil: a review. Ind Eng Chem Res 2012;51:14610-28.

[2] Guan G, Kusakabe K. Development of advanced biodiesel fuel production process. J Jpn Petrol Inst 2012;55:171-81.

[3] Gole VL, Gogate PR. A review on intensification of synthesis of biodiesel from sustainable feed stock using sonochemical reactors. Chem Eng Process 2012;53:1-9.

[4] Sharma YC, Singh B, Korstad J. Advancements in solid acid catalysts for ecofriendly and economically viable synthesis of biodiesel. Biofuel Bioprod Bior 2011:5:69-92.

[5] Erickson DR. Neutralization. In: Erickson DR, editor. Practical handbook of soybean production and utilization. Champaign, Illinois: AOCS Press; 1995. p. $184-202$.

[6] Sharma Y, Singh B, Upadhyay S. Advancements in development and characterization of biodiesel: a review. Fuel 2008;87:2355-73.

[7] Alptekin E, Canakci M, Sanli H. Evaluation of leather industry wastes as a feedstock for biodiesel production. Fuel 2012;95:214-20.

[8] Gürü M, Koca A, Can Ö, Çınar C, Şahin F. Biodiesel production from waste chicken fat based sources and evaluation with $\mathrm{Mg}$ based additive in a diesel engine. Renew Energy 2010;35:637-43.

[9] Alptekin E, Canakci M. Optimization of pretreatment reaction for methyl ester production from chicken fat. Fuel 2010;89:4035-9.

[10] Borges ME, Diaz L. Recent developments on heterogeneous catalysts for biodiesel production by oil esterification and transesterification reactions: a review. Renew Sust Energy Rev 2012;16:2839-49.

[11] Atadashi IM, Aroua MK, Aziz ARA, Sulaiman NMN. The effects of catalysts in biodiesel production: a review. J Ind Eng Chem 2013;19:14-26.

[12] Islam A, Taufiq-Yap YH, Chu C-M, Chan E-S, Ravindra P. Studies on design of heterogeneous catalysts for biodiesel production. Process Saf Environ 2013;91:131-44.

[13] Tariq M, Ali S, Khalid N. Activity of homogeneous and heterogeneous catalysts, spectroscopic and chromatographic characterization of biodiesel: a review. Renew Sust Energy Rev 2012;16:6303-16.

[14] Nandiwale KY, Sonar SK, Niphadkar PS, Joshi PN, Deshpande SS, Patil VS, et al. Catalytic upgrading of renewable levulinic acid to ethyl levulinate biodiesel using dodecatungstophosphoric acid supported on desilicated H-ZSM-5 as catalyst. Appl Catal a-Gen 2013;460:90-8.

[15] Patel A, Narkhede N. 12-Tungstophosphoric acid anchored to zeolite $\mathrm{H}$ beta: synthesis, characterization, and biodiesel production by esterification of oleic acid with methanol. Energy Fuel 2012;26:6025-32.

[16] Babajide O, Musyoka N, Petrik L, Ameer F. Novel zeolite Na-X synthesized from fly ash as a heterogeneous catalyst in biodiesel production. Catal Today 2012;190:54-60.

[17] Mbaraka IK, McGuire KJ, Shanks BH. Acidic mesoporous silica for the catalytic conversion of fatty acids in beef tallow. Ind Eng Chem Res 2006;45: 3022-8.

[18] Mbaraka IK, Shanks BH. Design of multifunctionalized mesoporous silicas for esterification of fatty acid. J Catal 2005;229:365-73.

[19] Mbaraka IK, Shanks BH. Conversion of oils and fats using advanced mesoporous heterogeneous catalysts. J Am Oil Chem Soc 2006;83:79-91.

[20] Lotero E, Liu YJ, Lopez DE, Suwannakarn K, Bruce DA, Goodwin JG. Synthesis of biodiesel via acid catalysis. Ind Eng Chem Res 2005;44:5353-63.

[21] Feng Y, He B, Cao Y, Li J, Liu M, Yan F, et al. Biodiesel production using cationexchange resin as heterogeneous catalyst. Bioresource Technol 2010;101:1518-21.

[22] Kim M, Lee H-s, Yoo SJ, Youn Y-S, Shin YH, Lee Y-W. Simultaneous synthesis of biodiesel and zinc oxide nanoparticles using supercritical methanol. Fuel 2013;109:279-84.

[23] Shao GN, Sheikh R, Hilonga A, Lee JE, Park Y-H, Kim HT. Biodiesel production by sulfated mesoporous titania-silica catalysts synthesized by the sol-gel process from less expensive precursors. Chem Eng J 2013;215:600-7.

[24] Chen C-L, Huang C-C, Tran D-T, Chang J-S. Biodiesel synthesis via heterogeneous catalysis using modified strontium oxides as the catalysts. Bioresource Technol 2012;113:8-13.

[25] Park Y-M, Chung S-H, Eom HJ, Lee J-S, Lee K-Y. Tungsten oxide zirconia as solid superacid catalyst for esterification of waste acid oil (dark oil). Bioresource Technol 2010;101:6589-93.

[26] Lee J-S, Saka S. Biodiesel production by heterogeneous catalysts and supercritical technologies. Bioresource Technol 2010;101:7191-200.

[27] Kim M, DiMaggio C, Yan S, Wang H, Salley SO, Ng KYS. Performance of heterogeneous $\mathrm{ZrO} 2$ supported metaloxide catalysts for brown grease esterification and sulfur removal. Bioresource Technol 2011;102:2380-6.

[28] Rattanaphra D, Harvey AP, Thanapimmetha A, Srinophakun P. Kinetic of myristic acid esterification with methanol in the presence of triglycerides over sulfated zirconia. Renew Energy 2011;36:2679-86.

[29] Shuit SH, Yee KF, Lee KT, Subhash B, Tan SH. Evolution towards the utilisation of functionalised carbon nanotubes as a new generation catalyst support in biodiesel production: an overview. RSC Advances 2013;3:9070-94.

[30] SathyaSelvabala V, Varathachary TK, Selvaraj DK, Ponnusamy V, Subramanian S. Removal of free fatty acid in Azadirachta indica (Neem) seed oil using phosphoric acid modified mordenite for biodiesel production. Bioresource Technol 2010;101:5897-902. 
[31] do Nascimento LAS, Angelica RS, da Costa CEF, Zamian JR, da Rocha Filho GN. Comparative study between catalysts for esterification prepared from kaolins. Appl Clay Sci 2011;51:267-73.

[32] Zatta L, Ferreira da Costa Gardolinski JE, Wypych F. Raw halloysite as reusable heterogeneous catalyst for esterification of lauric acid. Appl Clay Sci 2011;51:165-9.

[33] Guo F, Xiu Z-L, Liang Z-X. Synthesis of biodiesel from acidified soybean soapstock using a lignin-derived carbonaceous catalyst. Appl Energy 2012:98:47-52.

[34] Pua Fl, Fang Z, Zakaria S, Guo F, Chia C-h. Direct production of biodiesel from high-acid value Jatropha oil with solid acid catalyst derived from lignin. Biotechnol Biofuels 2011;4:1-8.

[35] Chin LH, Abdullah AZ, Hameed BH. Sugar cane bagasse as solid catalyst for synthesis of methyl esters from palm fatty acid distillate. Chem Eng J 2012;183:104-7.

[36] Fu Z, Wan H, Hu X, Cui Q, Guan G. Preparation and catalytic performance of a carbon-based solid acid catalyst with high specific surface area. React Kinet Mech Cat 2012;107:203-13.

[37] Dehkhoda AM, West AH, Ellis N. Biochar based solid acid catalyst for biodiesel production. Appl Catal A-Gen 2010;382:197-204.

[38] Chang B, Fu J, Tian Y, Dong X. Soft-template synthesis of sulfonated mesoporous carbon with high catalytic activity for biodiesel production. RSC Advances 2013:3:1987-94.

[39] Mar WW, Somsook E. Sulfonic-functionalized carbon catalyst for esterification of high free fatty acid. Procedia Eng 2012;32:212-8.

[40] Rao BVSK, Chandra Mouli K, Rambabu N, Dalai AK, Prasad RBN Carbon-based solid acid catalyst from de-oiled canola meal for biodiesel production. Catal Commun 2011;14:20-6.

[41] Xia P, Liu FJ, Wang C, Zuo SF, Qi CZ. Efficient mesoporous polymer based solid acid with superior catalytic activities towards transesterification to biodiesel. Catal Commun 2012;26:140-3.

[42] Stellwagen DR, van der Klis F, van Es DS, de Jong KP, Bitter JH. Functionalized carbon nanofibers as solid-acid catalysts for transesterification. Chemsuschem 2013;6:1668-72.

[43] Zhou L, Dong B, Tang S, Ma H, Chen C, Yang X, et al. Sulfonated carbon catalyzed oxidation of aldehydes to carboxylic acids by hydrogen peroxide. J Energy Chem 2013;22:659-64.

[44] Chang B, Fu J, Tian Y, Dong X. Multifunctionalized ordered mesoporous carbon as an efficient and stable solid acid catalyst for biodiesel preparation. J Physl Chem C 2013;117:6252-8.

[45] Zhang X, Wang Y, Hao C, Wu P, Jiang Z, Study on the preparation and catalytic property of sulfonated ordered mesoporous carbon. In: Kida K, editor, Advanced Materials and Engineering Materials Ii, 2013. p. 484-87.
[46] Hou K, Zhang A, Gu L, Liu M, Guo X. Efficient synthesis and sulfonation of ordered mesoporous carbon materials. J Colloid Interf Sci 2012;377:18-26.

[47] Ayrilmis N, Kaymakci A, Ozdemir F. Sunflower seed cake as reinforcing filler in thermoplastic composites. J Appl Polym Sci 2012:1170-8.

[48] Fernández-Cegrí V, Raposo F, de la Rubia MA, Borja R. Effects of chemical and thermochemical pretreatments on sunflower oil cake in biochemical methane potential assays. J Chem Technol Biotechnol 2013;88:924-9.

49] Gelbard G, Bres O, Vargas RM, Vielfaure F, Schuchardt UF. H-1 nuclearmagnetic-resonance determination of the yield of the transesterification of rapeseed oil with methanol. J Am Oil Chem Soc 1995;72:1239-41.

[50] Brasil AN, Usina portátil para simulação industrial de processos de produção de biodiesel por irradiação por ultrassom, in: Energias BEd, editor, Brasil, 2011.

[51] Vieira Grossi C, de Oliveira Jardim E, de Araújo MH, Lago RM, da Silva MJ. Sulfonated polystyrene: a catalyst with acid and superabsorbent properties for the esterification of fatty acids. Fuel 2010;89:257-9.

[52] Dresselhaus MS, Jorio A. Souza AG, Saito R. Defect characterization in graphene and carbon nanotubes using Raman spectroscopy. Philos Trans R Soc A-Math Phys Eng Sci 2010;368:5355-77.

53] Evon P, Vandenbossche V Rigal L Manufacturing of renewable and biodegradable fiberboards from cake generated during biorefinery of sunflower whole plant in twin-screw extruder: Influence of thermo-pressing conditions. Polym Degrad Stabil 2012;97:1940-7.

[54] Kacurakova M, Wilson RH. Developments in mid-infrared FT-IR spectroscopy of selected carbohydrates. Carbohydr Polym 2001;44:291-303.

[55] Chen G, Fang B. Preparation of solid acid catalyst from glucose-starch mixture for biodiesel production. Bioresource Technol 2011;102:2635-40.

[56] Rao BVSK, Mouli KC, Rambabu N, Dalai AK, Prasad RBN. Carbon-based solid acid catalyst from de-oiled canola meal for biodiesel production. Cata Commun 2011;14:20-6.

[57] Chang B, Tian Y, Shi W, Liu J, Xi F, Dong X. Magnetically separable porous carbon nanospheres as solid acid catalysts. RSC Adv 2013;3:20999-1006.

[58] Özçimen D. An Approach to the Characterization of Biochar and Bio-Oil. Yildiz Technical University, 2013.

[59] Guthrie JP. Hydrolysis of esters of oxy acids: pKa values for strong acids; Brønsted relationship for attack of water at methyl; free energies of hydrolysis of esters of oxy acids; and a linear relationship between free energy of hydrolysis and pKa holding over a range of $20 \mathrm{pK}$ units. Can J Chem 1978;56:2342-54

[60] Toda M, Takagaki A, Okamura M, Kondo JN, Hayashi S, Domen K, et al. Biodiesel made with sugar catalyst. Nature 2005;438:178. 